formerly more extensive Bure-Yare-Waveney estuary.

Evidence from the field of historical geography assembled by Mr. C. T. Smith and the results of archæological work, interpreted by $\mathrm{Mr}$. Charles Green and $\mathrm{Mr}$. J. N. Hutchinson, supported the new hypothesis. The combined evidence was published under the title The Making of the Broads (No. 3 in the Royal Geographical Society's Research Series).

At tho Norwich symposium, Dr. Lambert reviewed the physiographical and botanical evidence on which their findings are based. Boring has revealed that the basins in which the Broads lie have uniformly steep sides and virtually level floors with resulting rectangular profiles. Islands and peninsulas with similar vertical sides have exactly the same stratigraphy as the surrounding fenland. They are interpreted as balks left in the extraction of peat to a depth of 10-12 ft. In old surveys, including tithe and enclosure maps and in modern air photographs these islands and peninsulas can be correlated with boundaries between holdings.

Two of the more important difficulties in accepting human agencies to account for the existence of the Broads relate to the enormous amount of peat involved and the need to postulate changes in waterlevel, which would permit the excavation of peat to depths well below those of present-day workings, and eventually lead to the flooding of tho pits. Mr. C. T. Smith described the search for evidence which would resolve these difficulties. Nothing in the published records of broadland suggested an 'artificial' origin. The large-scale changes caused by the extraction of an estimated nine hundred million cubic feet of peat and the flooding of the workings appear to have made no impact on local tradition and folk-lore. However, a careful and detailed study of documents and maps supplied strong circumstantial evidence in support of the deductions based on the stratigraphy. References to turbary and the sale and consumption of turves show that large-scale peat digging was well under way by the twelfth century. Muoh of the consumption must have gone unrecorded but examination of terriers, deeds, account rolls and registers, such as those of Norwich Cathedral Priory and St. Benet's Abbey, give an indication of the scale of operations. The purchase of 400,000 turves by Norwich Cathedral Priory in 1316 is typical. These same records also show that by the beginning of the fourteenth century the flooding of the turf pits had begun. While extraction continued well into the fifteenth century it was increasingly difficult and expensive, and involved first the dredging of peat with simple scoops and then the making of turves. Soon other fuels replaced turves in the records and references to turbaries were replaced by references to open water and fisheries.

The archæological evidence put forward by $\mathrm{Mr}$. Charles Green showed that emergence from the Romano-British submergence reached a peak in the thirteenth century. The excavations on the site of the power-station at South Denes, Great Yarmouth, indicate a relative fall in sea-level of the order of $13 \mathrm{ft}$. This means that deep extraction of peat from the Norfolk valley floors was possible in 'dry' pits. Similar evidence revealed a reversal of the downward movement of sea-level, initiated toward the end of the thirteenth century, which clearly accounts for the slow but inexorable flooding of the peat-diggings and the formation of what we now call the Norfolk Broads.

As a piece of scientific detection, the story unfolded to the Norwich symposium was a masterpiece. It is, however, not only of historical or academic interest. The state of dynamic change, which Dr. Lambert showed to underlie all the present-day problems of the Broads, both scientific and practical, stems directly from these surprising beginnings. The vegotation of broadland does not, as was formerly thought, result from the overgrowing of large continuous sheets of open water. There is a fundamental distinction between the vegetation which has grown up on the solid fen, much modified by a variety of human interference, and that which is encroaching on the basin of the Broads. The filling of the manmade lakes with freshwater mud, which has made this encroachment possible, only reached a critical stage about the beginning of the nineteenth century. It has, however, already resulted in a rapid reduction of the open water available to the holiday maker. Dr. Lambert is continuing her ecological work in the Broads, but the number of problems which still remain to be tackled, some of which she touched on, is very largo. The need for more research was the theme of the diseussion which followed the reading of papers. Any new work which may be instituted will owe much to Dr. Lambert and Mr. Jennings and their colleagues.
C. KIDSON

\title{
THE SOIL AS AN ENVIRONMENT FOR ANIMAL LIFE
}

A SYMPOSIUM on "The Soil as an Environment I for Animal Life" was held on September 1 by Section D (Zoology) at the Norwich meeting of the British Association for the Advancement of Science.

Sir John Russell pointed out that soil contains four groups of components: a minoral framework, organic matter, mineral matter from the bodies of organisms and soil solution. The relative proportions of organic and inorganic substances largely determine the suitability of the soil as a habitat: arable soils, with the lowest organic content, contain fewest organisms, while grasslands are usually richer.

The organio matter is derived from plants, their remains being reduced by organisms in the soil to their original simple origins: residues remaining form the humus. This is black, has colloidal proper- ties, and in the elimate of Great Britain contains about ten times as much carbon as nitrogen. If non-nitrogenous substances are added to the soil, atmospheric nitrogen is fixed, while if nitrogenous substances are added the humus splits off nitrogen as ammonia or nitrogen gas.

The mineral framework of the soil contains particles ranging from $2 \mathrm{~mm}$. to $0.02 \mathrm{~mm}$. in equivalent diameter: these are the sand and silt. Clay particles less than $2 \mu$ in equivalent diameter differ from the larger particles; they carry a negative electric charge, and can attract positively charged ions such as calcium and hold them against leaching. Clay is colloidal, with a great power of absorbing water: it expands on wetting and shrinks on drying, producing large cracks in the soil. 
Calcium compounds, especially calcium carbonate, are as important as clay and organic matter in their biotic effects. While calcium carbonate is present the soil remains neutral, but as it dissolves in rainwater containing carbon dioxide and is leached out the soil becomes acid. The flora and fauna then become more restricted, though some organisms, such as Plasmodiophora and the amœbæ, do well. At a certain stage earthworms disappear: plant residues then remain on the surface and decompose there, forming 'mor'.

Organic and mineral soil components mingle to form crumbs, the optimum crumb size for plant growth ranging from 5 to $1 \mathrm{~mm}$. Good crumbs are stable even under rainfall, while bad ones break down in wet conditions, forming a slurry. Mineral particles and crumbs have pore spaces between them, the total pore space being increased by crumb formation.

For organisms to survive in the soil, five conditions are necessary: living space, air, water, suitable temperature and freedom from injurious factors. The pore spaces provide the living room, and are also the water reservoirs. The chief cause of water loss is suction by plant roots: evaporation causes less than might be supposed. The surface layer dries quickly and protects the soil beneath, and there is no evidence of capillary movement of water from wetter to drier parts except just above the water table.

Diffusion of air into the pore spaces is very rapid, and the composition of air 6 in. down on arable land differs little from that of the atmosphere, except that the amount of carbon dioxide is greater, reaching 0.1 per cent on bare soil and 0.2 per cent under crops. In grassland soil the carbon dioxide content is greater : 3 per cent has been recorded. This high concentration does not appear to affect the soil population seriously.

Soil temperatures reflect those of the air, but fluctuations are heavily damped. Variations are greater on arable land than on grassland.

Harmful factors are numerous and may be drastic. These include acids, products of anaerobic decomposition such as hydrogen sulphide, the presence of parasites and predators, etc. Soil bacteria act as scavengers, removing harmful substances very effectively.

The question of food for the soil fauna has been studied most fully by the foresters. Leaves and twigs form litter on the soil surface: in it a mixed population develops and makes the primary attack on the food material it contains. Then follows the secondary decomposition, in which organisms nurtured in the first stage are eaten by predators that either capture their prey or poison it and feed on its decomposing body; also the excretions of primary decomposers are eaten by coprophagous animals. The final residue is humus; this persists in the soil, but is slowly deeomposed, mainly by bacteria, the final end-products being carbon dioxide, ammonia, water and $a$ few mineral salts. These will be starting material for a new generation of plants.

Dr. F. Raw discussed "The Interdependence of the Soil and its Fauna". The soil can be considered an environment created by animal activity from weathered mineral substrate and plant remains. The material from which the soil developed, the climate and the vegetation influence the animal communities developing in the soil, and these in turn influence the soil profile. Agricultural practices that affect the fauna may produce great changes in the biological and physical properties of the soil.
The greatest diversity and abundance of soil animals are found in virgin habitats such as permanent grassland or woodland. The arthropods in a perman. ent grass field in Cambridgeshire included 17 orders or classes, including uncommon groups such as the Pauropoda and Protura. Smaller arthropods were especially numerous. About 70 per cent of the Arthropoda occurred in the top 6 in., though some groups were more numerous at lower levels. In general, the smaller forms live deeper in the soil.

In arable soil the arthropod population is greatly reduced. In the Barnfield mangold plots at Rothamsted, the plots receiving mineral fertilizers yielded about 15,000 individuals per square yard, while in the dunged plots the number of individuals was almost twice as great, and the population was more diverse. The same was true of the earthworms, though the dominant Lumbricus terrestris was less affected by dunging than other species.

Earthworms are the principal agents that bury plant remains, mix them with the soil and so accelerate decomposition and the release of plant nutrients. In undisturbed habitats their activity can have a profound effect on the soil profile, and their presence or absence can result in the development of two fundamentally different soil types, 'mull' and 'mor'. This was illustrated by measuring the amount of leaf litter buried by worms in several apple orchards near Wisbech, by placing a known number of weighed leaves on the ground beneath wire cages at leaf-fall and recording the number and weight of leaves remain. ing in the spring. In grass orchards the number and weight of leaves buried was closely correlated with the estimated fresh weight of Lumbricus terrestris. Some orchards had about 20 ewt. of $L$. terrestris per acre, which buried 8-9 cwt. dry weight of leavesenough to bury all the leaf-fall. Cultivation did not appear to affect the abundance of $L$. terrestris greatly, nor did regular applications of farmyard manure or compost.

In a grass orchard with a long history of heavy spraying with copper fungicides $L$. terrestris was not found, although it was abundant in surrounding unsprayed soil. In this orchard no leaves were buried; they decomposed slowly on the surface, and a mat of partially decomposed leaves, about 2 in. thick, had accumulated, so that the soil profile had typical 'mor' characteristics.

"The Soil Fauna and its Contribution to Fertility" was the subject of Dr. A. Macfadyen's paper. The soil contains enormous numbers of individual animals, and their action appears to be three-fold. The larger species tunnel through the soil and carry litter downwards and mineral matter upwards: at the same time they aerate and drain the soil and, by crumb formation and in other ways, render it a good medium for the growth of higher plants and microorganisms.

The second function performed by the soil animals is a direct chemical one due to their foeding activities. They assist in the breakdown of litter in the soil, though here they make a poor showing compared with the micro-organisms.

The third property of the soil fauna has only recently come under investigation. It appears that, quite apart from their own direct metabolic effects on litter breakdown, soil animals act as catalysts of the metabolism of the bacteria, fungi and other microorganisms. This catalytic action appears to operate through the cropping of senescent colonies, the re-distribution of slow-moving food materials, the 
local removal of antibiotic substances, the re-concentration of nutrients and the spreading of spores to places where they can flourish. The biological properties of the microbes are such that high-energy food materials become inaccessible and energy becomes dammed up. The animals are the 'dambusters' that disperse the accumulations of energy and restore the flow-and with it the nutrients needed by the higher plants.

It is not known yet how important these catalytic actions are, nor which of them are the most significant. Clearly, over the whole range of soil types, from forest and pasture to moorland and degraded arable land, the details of the picture are going to vary enormously; but the few experiments reported indicate that the animals' 'catalytic' role greatly exceeds their metabolic role as decomposers.

Current experiments are aimed at building up a good knowledge of the metabolic rates of isolated organisms under conditions as close to those in Nature as possible. At the same time systems are being developed containing micro-organisms and essential soil constituents of varying degrees of complexity but with predictable metabolic behaviour. It is hoped to go on from there to introduce different kinds of animals into the cultures and observe their effects on total metabolism, and to analyse the biochemical basis of these effects. In this way it is planned to bridge the gap between field conditions and laboratory experiments.

Dr. C. L. Duddington discussed "Predacious Fungi and Soil Eelworms". Predacious fungi are microfungi that attack small animals, including protozoa, rotifiers and eelworms. They are abundant in most fertile soils. We can distinguish two kinds of predacious activity among the fungi that attack eelworms. Some capture eelworms alive, while others are internally parasitic, attacking the host through the agency of sticky spores or by other means. At least two species of Nematoctonus combine both methods. Most of the work on predacious fungi attacking eelworms has been concentrated on the trap-forming species.

In the common Arthrobotrys oligospora and others the eelworm traps consist of systems of sticky networks, formed from curled, anastomosing branches of the mycelium. Eelworms that happen to touch the networks stick to them like flies on a fly-paper. Other species, like Dactylella cionopaga, have short, sticky lateral branches, while in D. ellipsospora and others small sticky knobs are attached to the mycelium by short stalks.

Some predacious fungi have mechanical traps. In Dactylaria candida rings, composed of three curved cells, are attached to the mycelium by short stalks; eelworms accidentally pushing their heads into the rings become wedged. In some species, such as Dactylella doedycoides, the cells of the rings are sensitive to touch; if an eelworm passes its body into the ring the three cells swell suddenly inwards, holding the eelworm by constriction.

Whatever trapping mechanism is used, the end result is that the eelworm is killed, and its body is invaded by hyphre that consume its contents.

A survey of 49 British arable soils produced 82 records of predacious fungi, belonging to 20 different species. Arthrobotrys oligospora was the commonest: both eelworm-trapping and internally parasitic species were represented. There is direct evidence that predacious fungi prey on eelworms in the soil under natural conditions, for mycelium with traps and eaptives has been found on slides immersed in soil both in field plots and in the laboratory. There is also convincing evidence that their predacious activity is enhanced by the presence of decomposable organic matter in the soil. There is reason to believe that the organic matter affects the activity of the fungi directly and not, as has formerly been supposed, through its stimulating effect on the population of free-living eelworms in the soil.

The importance of predacious fungi in limiting the soil nematode population under natural conditions has yet to be fully investigated, but experiments on the use of predacious fungi for the biological control of plant pathogenic eelworms suggest that their effect is not negligible. Soil treatment designed to enhance the activity of predacious fungi was successful in controlling pineapple root-knot eelworm in Hawaii, and in Britain the number of larvæ of cereal root eelworm invading the roots of oat seedlings has been significantly reduced by soil inoculation with Dactylella thaumasia combined with the addition of organic matter to stimulate the fungus.
C. L. Dudinaton

\section{DOMESTIC FOOD CONSUMPTION AND EXPENDITURE, 1959}

T HE survey for 1959 of the National Food Survey Committee * completes twenty years of continuous recording of domestic food consumption in Britain. Two reports cover the years 1940-49 and since 1950 a report has boen published each year. These twenty years have seen a complete change from severe restriction in food supplies, followed by a period of gradual increase, to the point recently reached at which the housewife with money to spare looks for greater variety and shows a preference for what may be called 'convenience foods', procossed and packed to save time and troublo.

A gap necessarily intervenes between the year of survey and the publication of these annual reports.

* Ministry of Agriculture, Fisheries and Food. Domestic Food Consumption and expenditure 1959: Annual Report of the National Food surve net.
As a result, they often clarify and extend facts already known in a general way. For example, the present report throws light on the increase in expenditure on food known to be taking place during the period under review. The everage weekly expenditure a head increased from $28 s$. $5 d$. in 1958 to $29 s$. $3 d$. in 1959. This was partly due to an increase in the price of foods such as butter, meat, cheese and fruit, but there was also a shift in demand from staple foods such as bread, flour, potatoes and fresh fish to fresh fruit, fresh green vegetables and a wide variety of processed foods. Expenditure on processed foods prepared ready for the table, which include canned and frozen foods, cakes, pastries and biscuits, has risen from $4 s$. $3 d$. a head a weok in 1955 to 58. 5d. in 1959. Doubtless, as the range of such foods increases and advertising becomes more clamorous, 